\title{
MERGULHO DO CORPO
}

Taciana Nogueira

Taciana Nogueira, natural de São José dos Salgados-MG, reside em Belo Horizonte desde 2010. Formada em Artes Gráficas-Artes

Visuais pela UFMG, atua nos campos da video-arte, fotografia aistes gráficas. É professora de Artes na rede pública de ensino artes grálicas. É a pelas artesanias.

tacianasalgado@gmail.com

INSTAGRAM: @taciananogueira 


A 



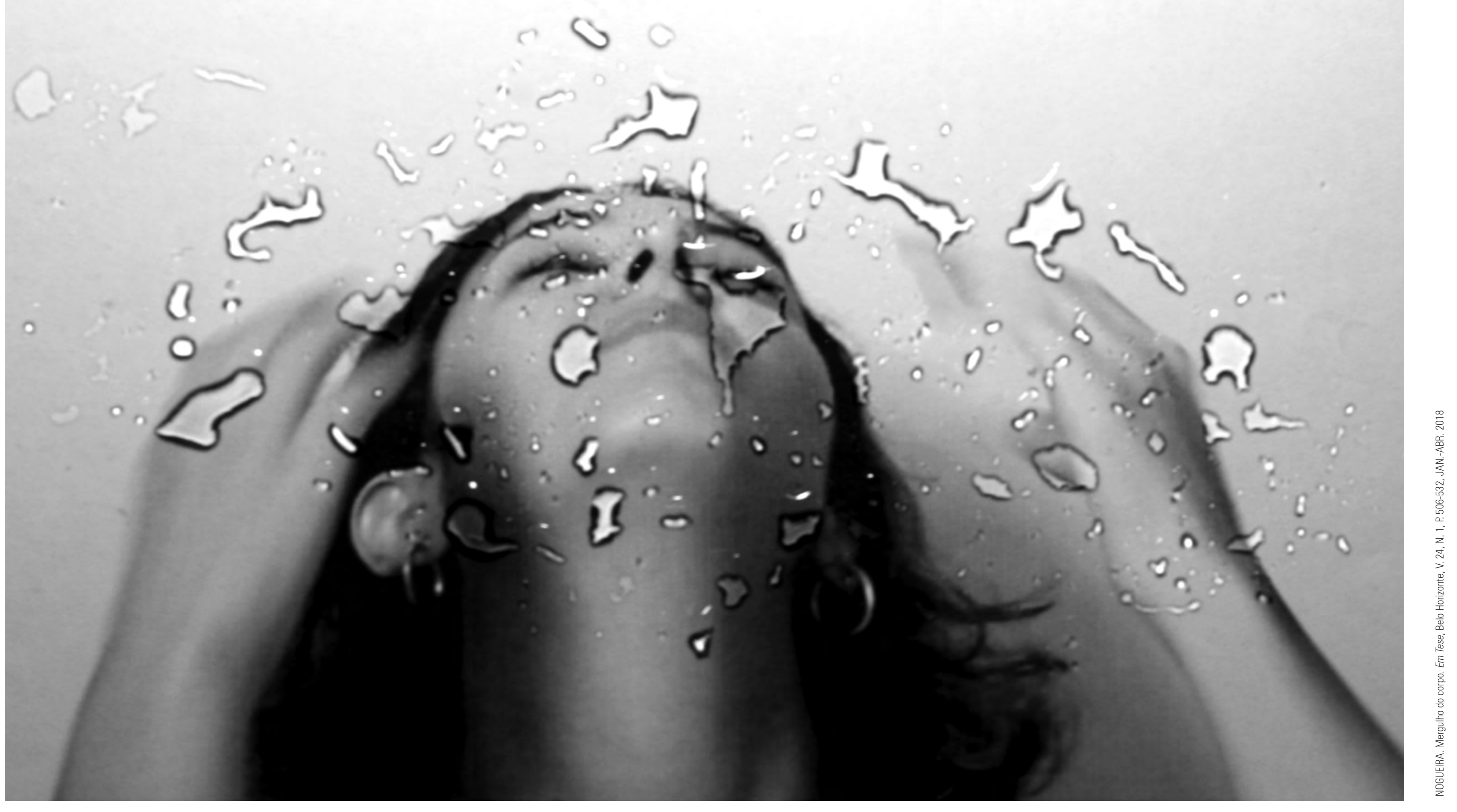




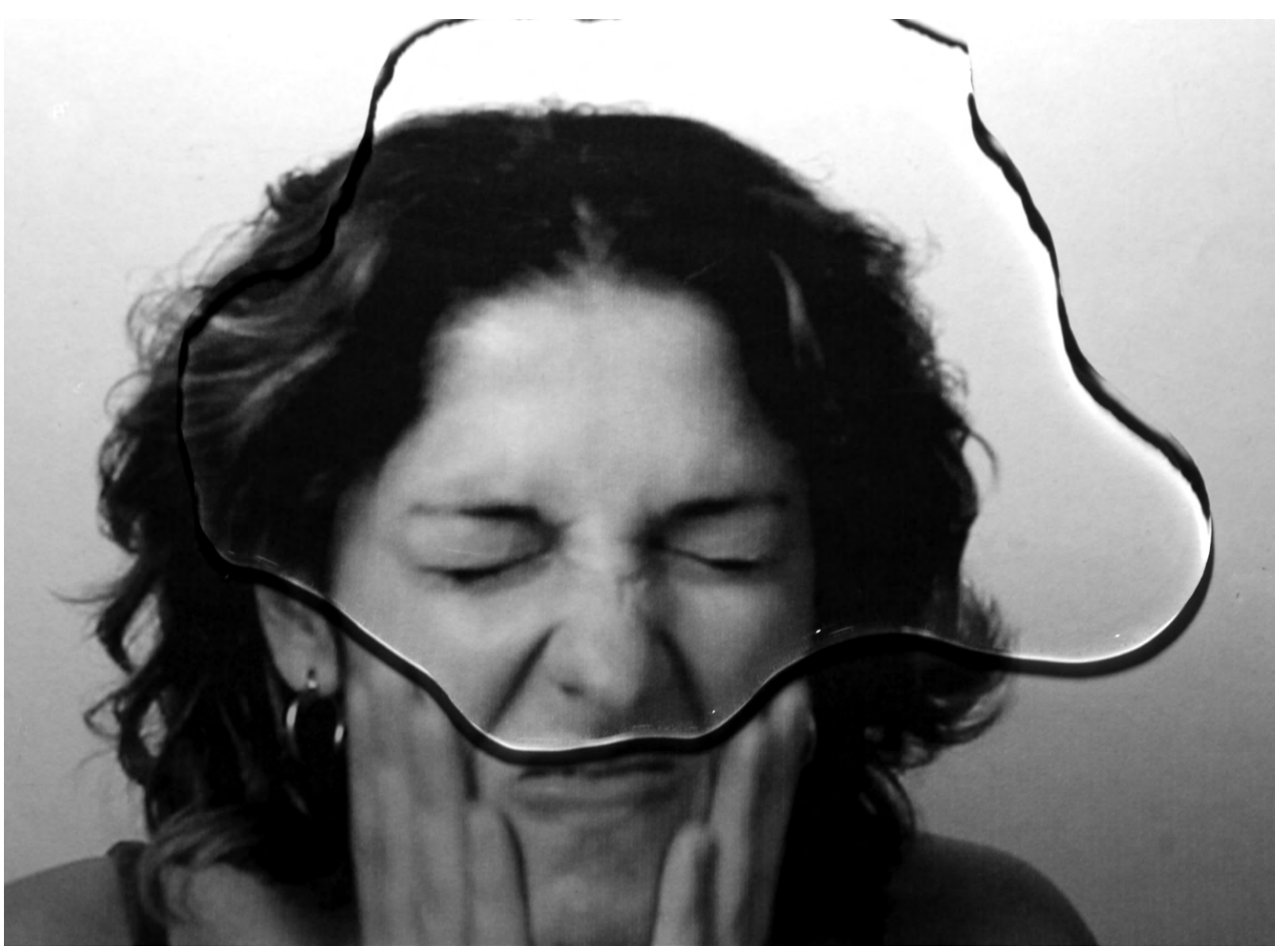




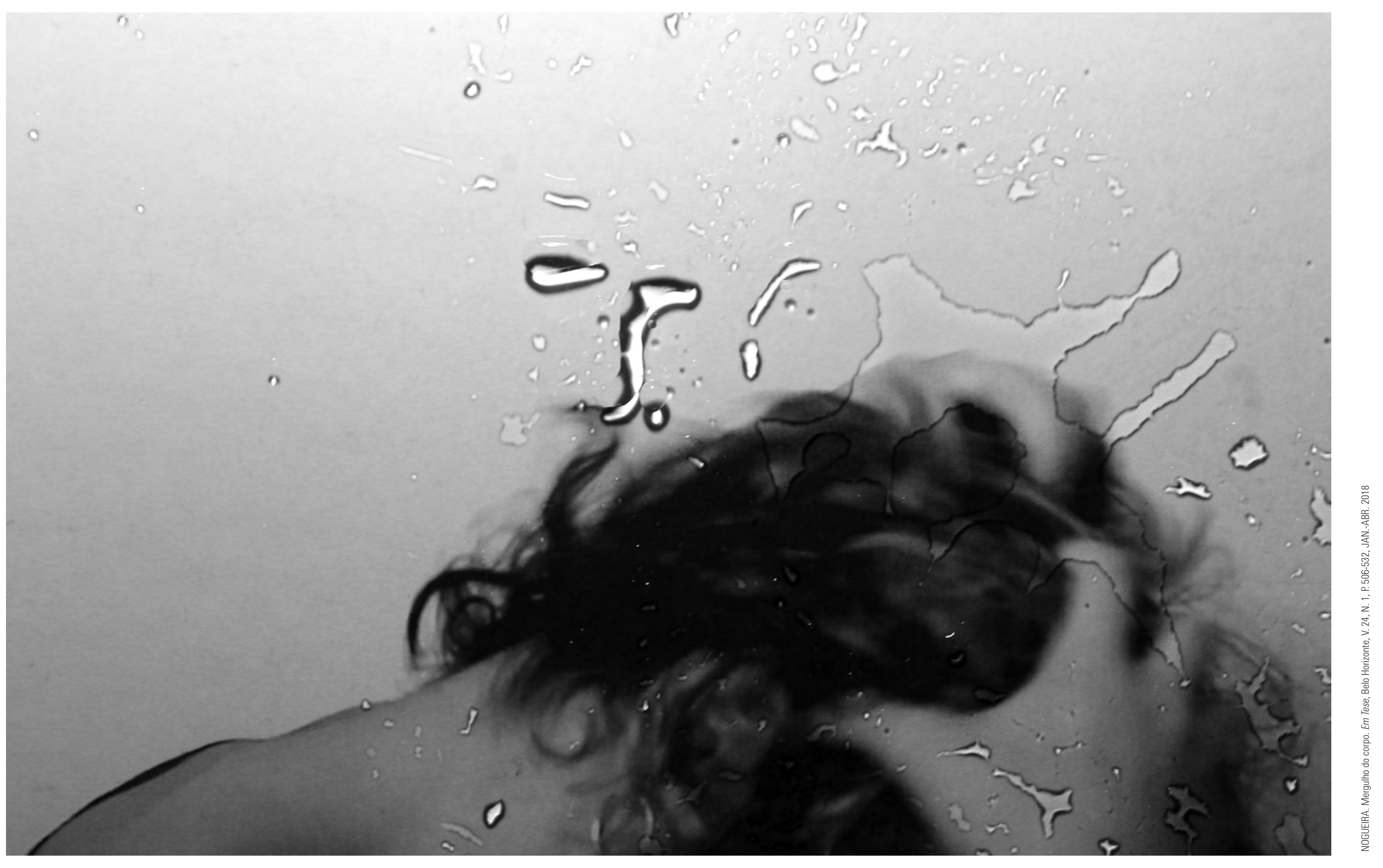




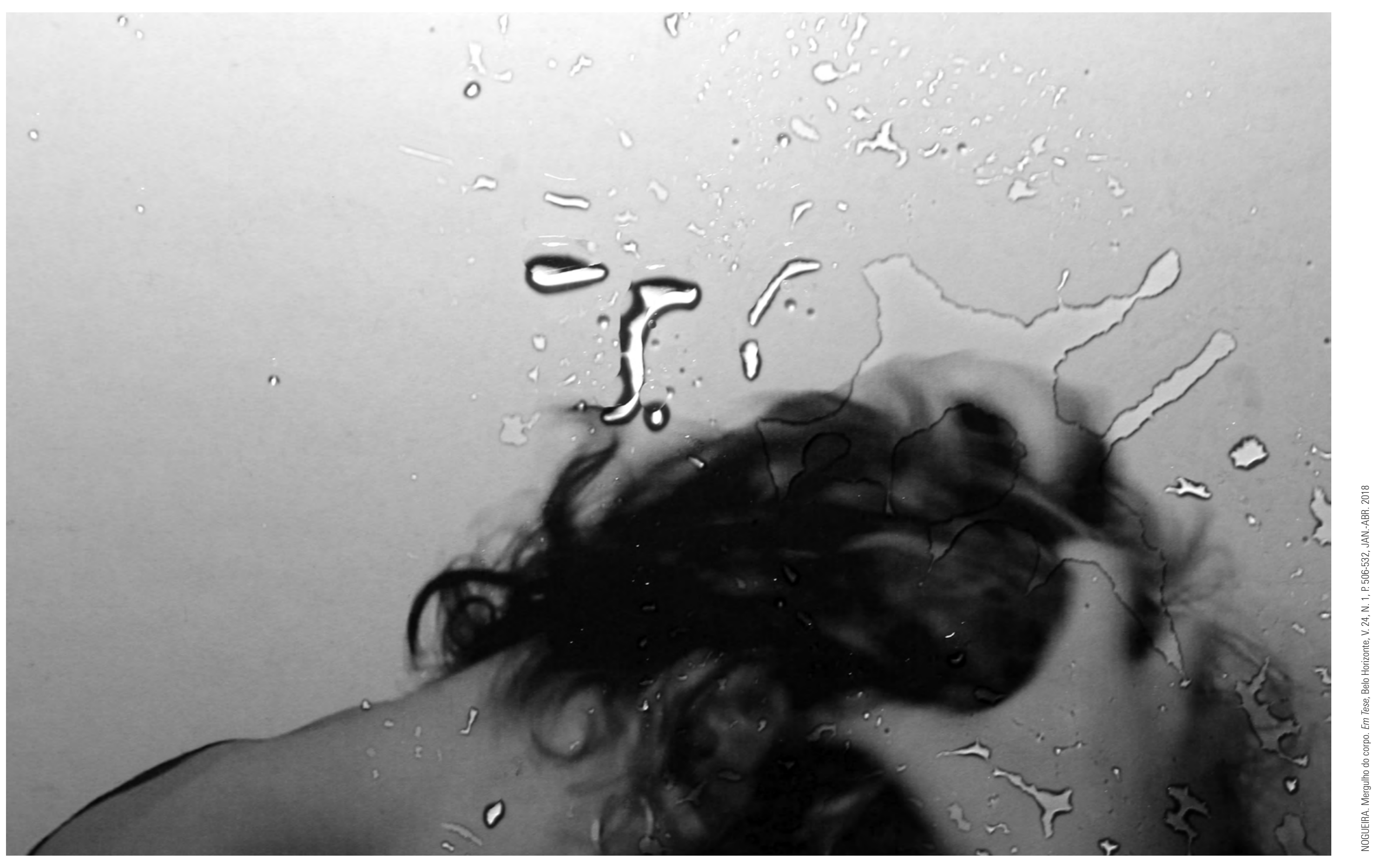




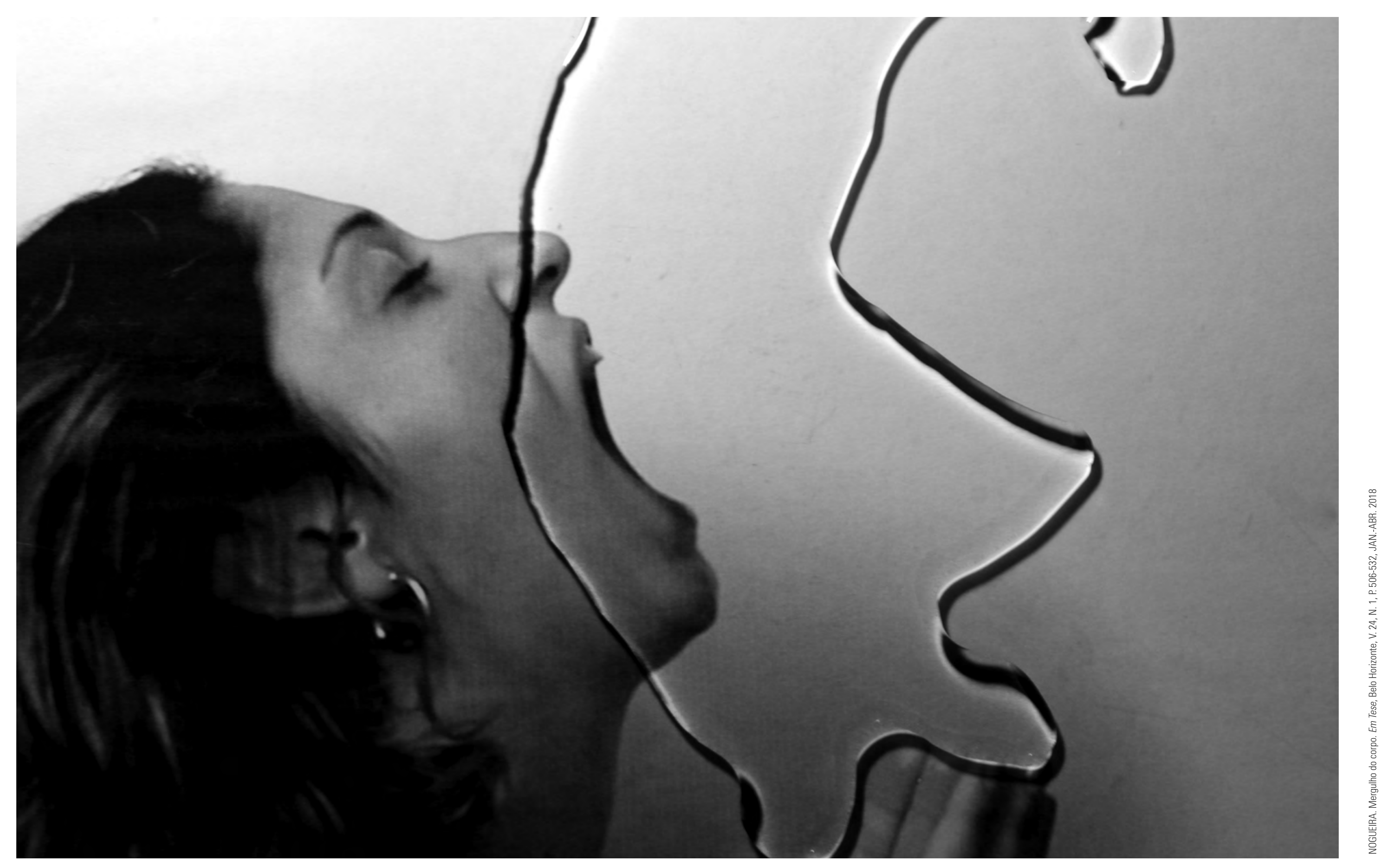


$0 \mathrm{c} 3 \mathrm{~s}$

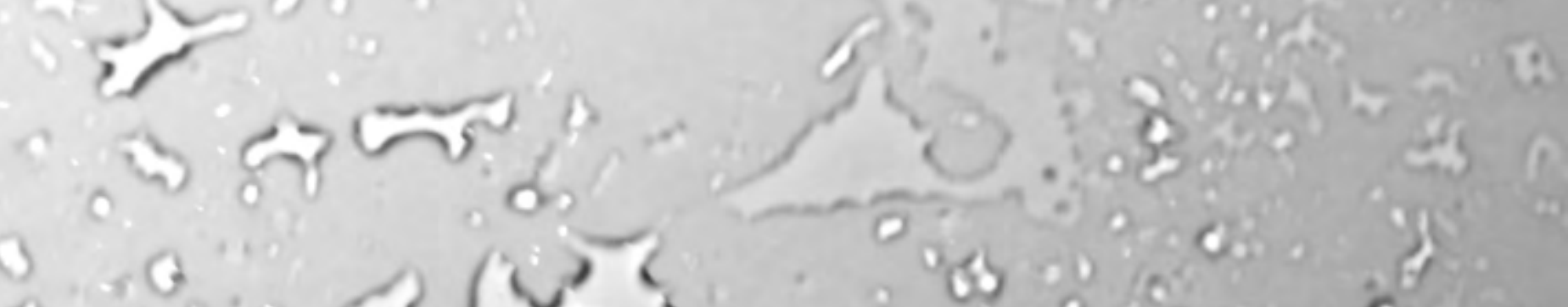

a o o th?

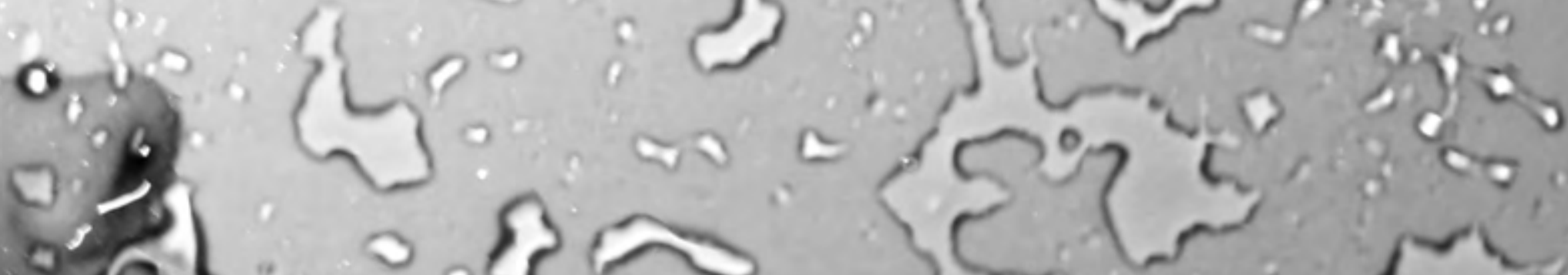
- zir un oरक

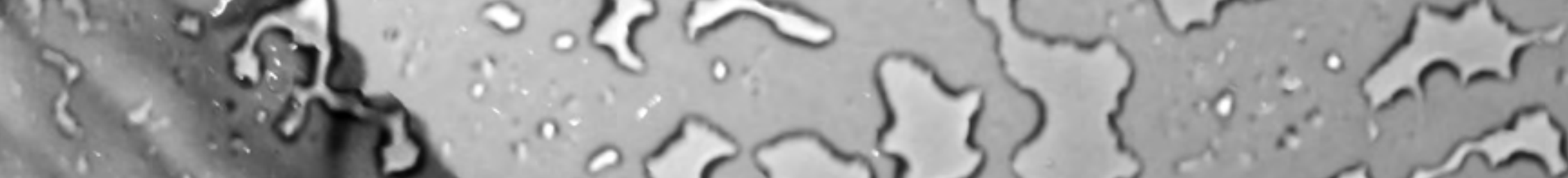

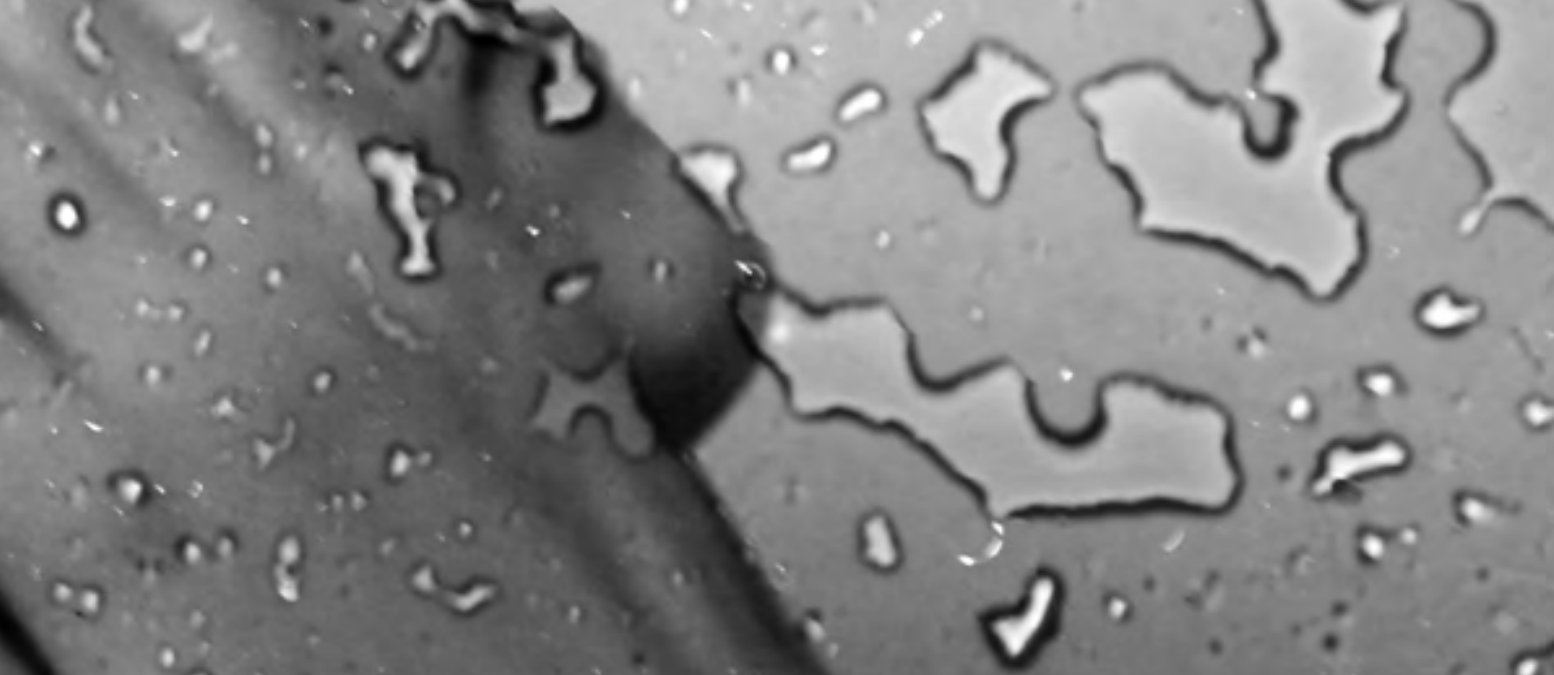

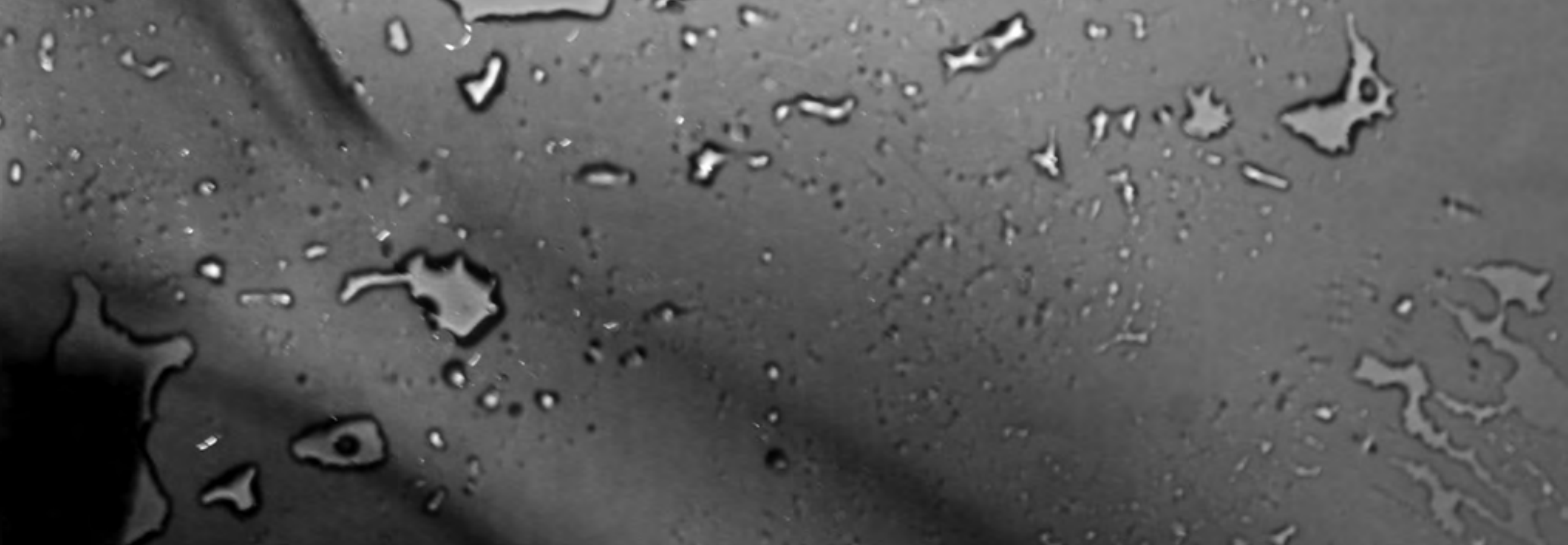





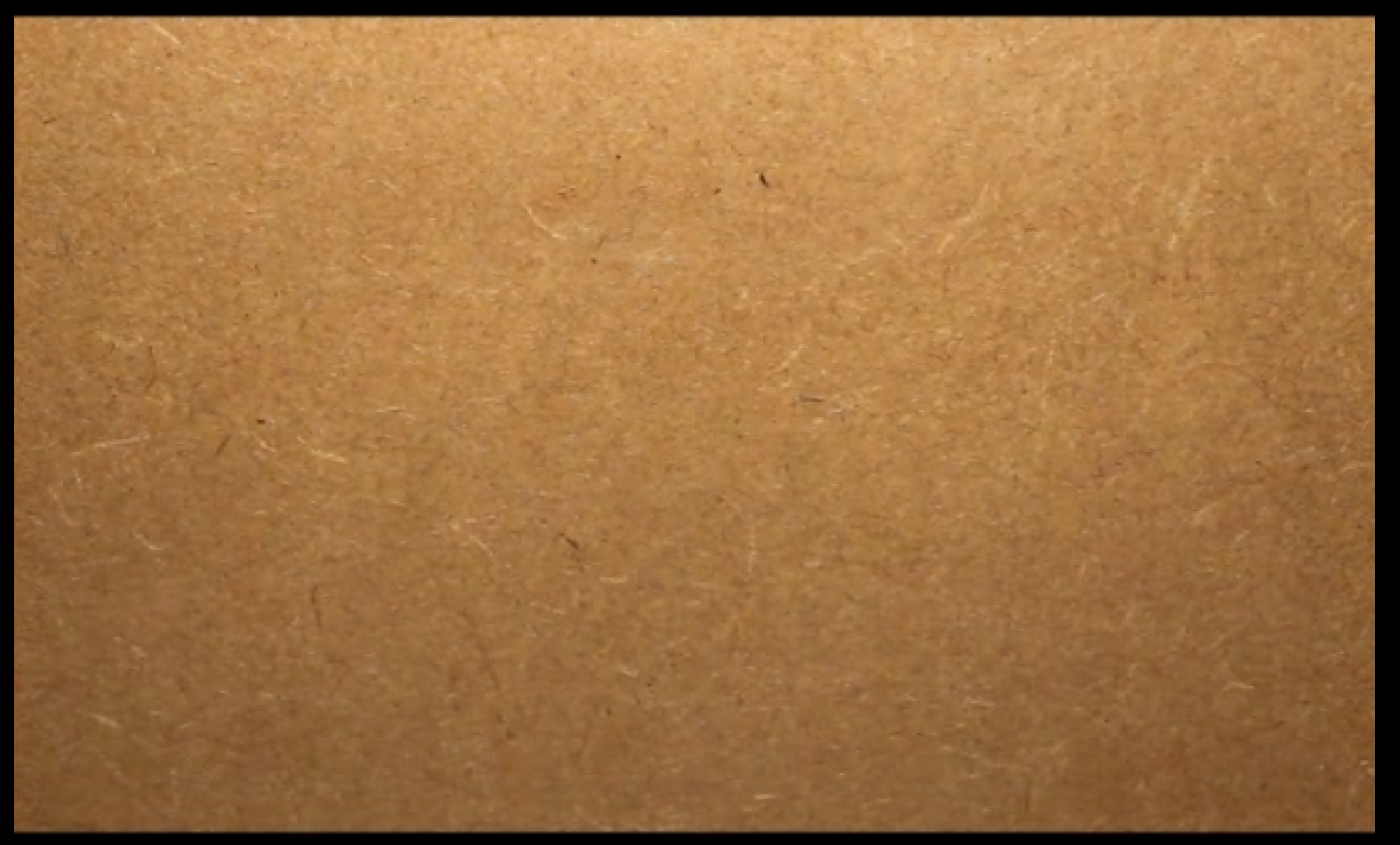




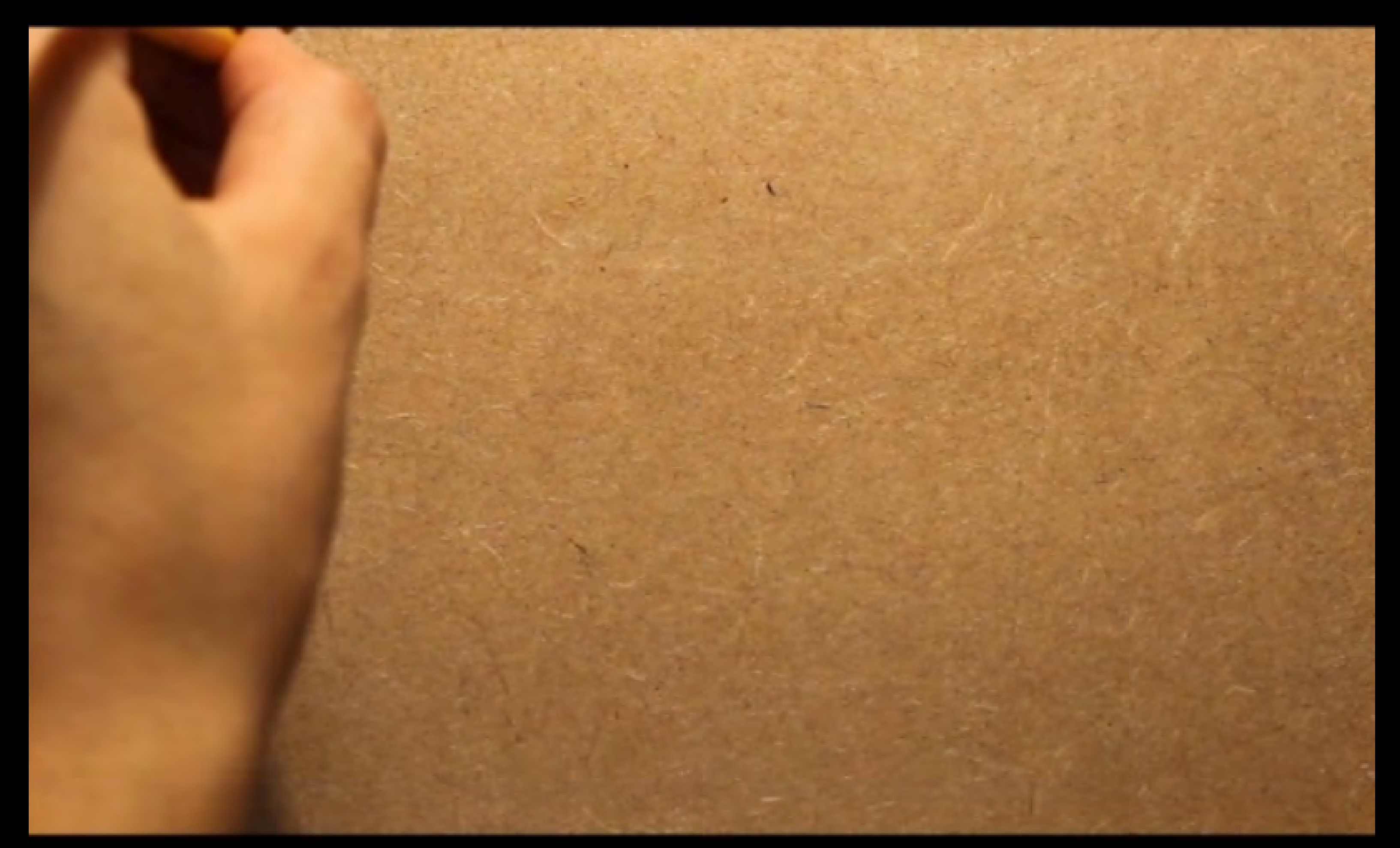




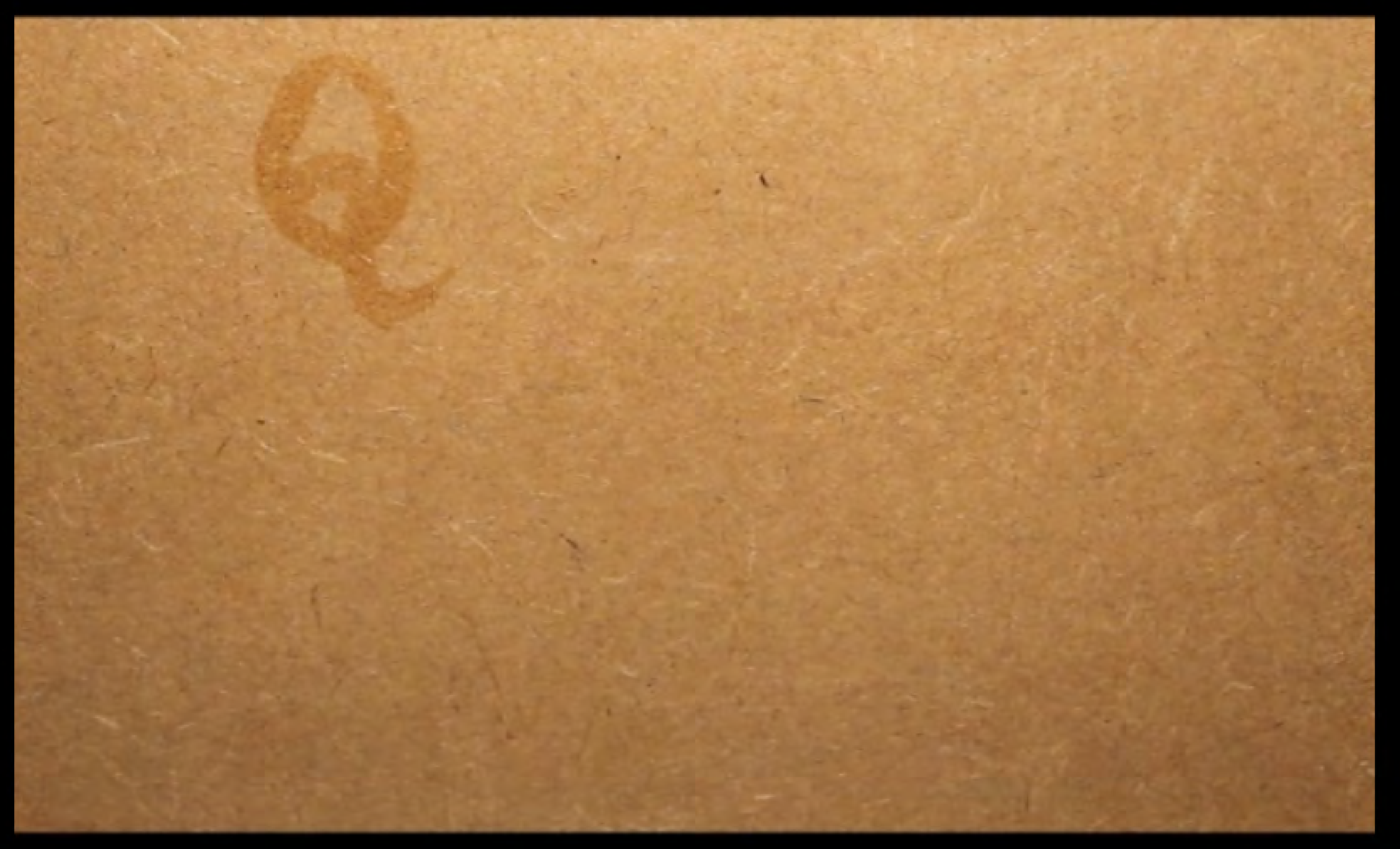




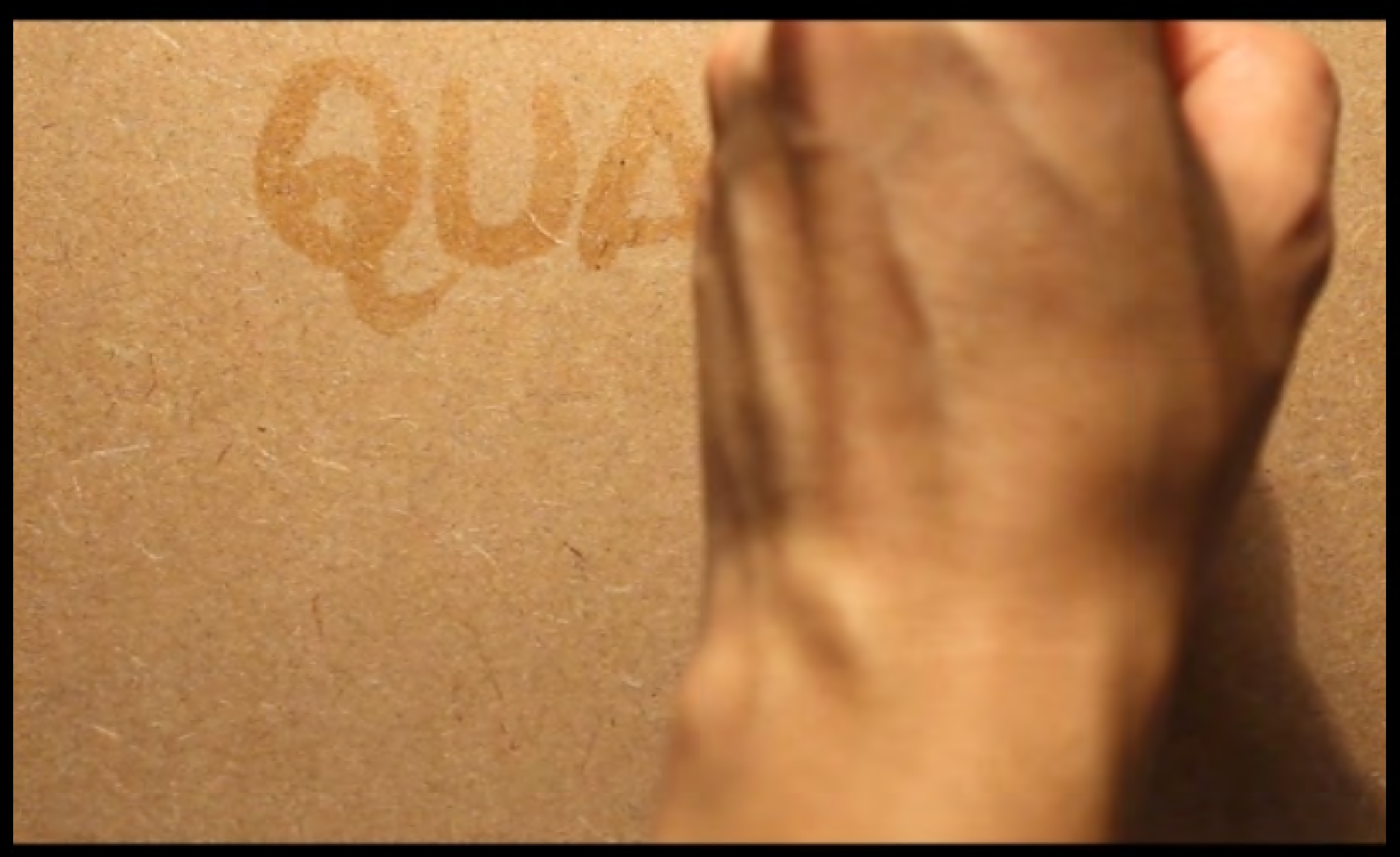




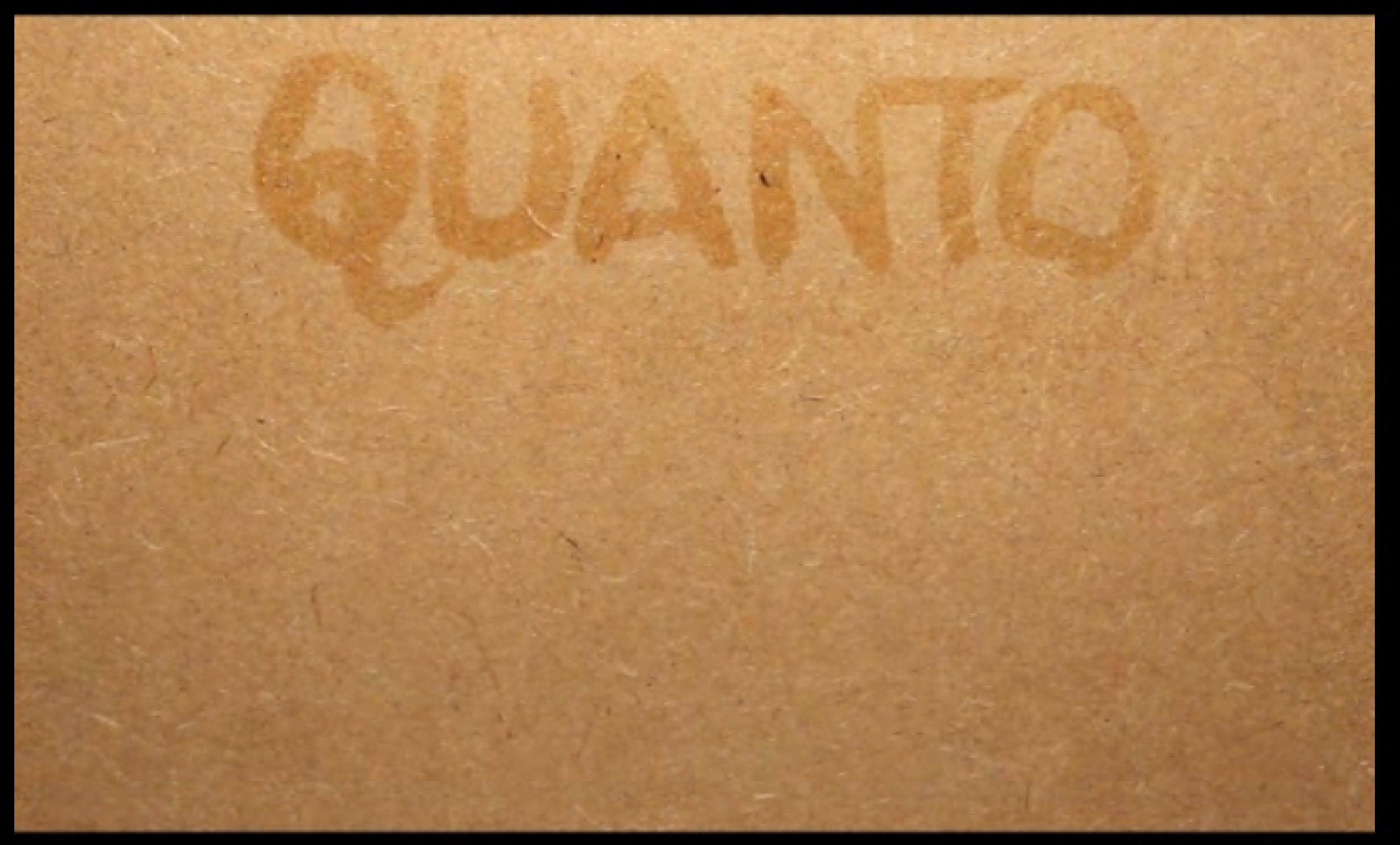




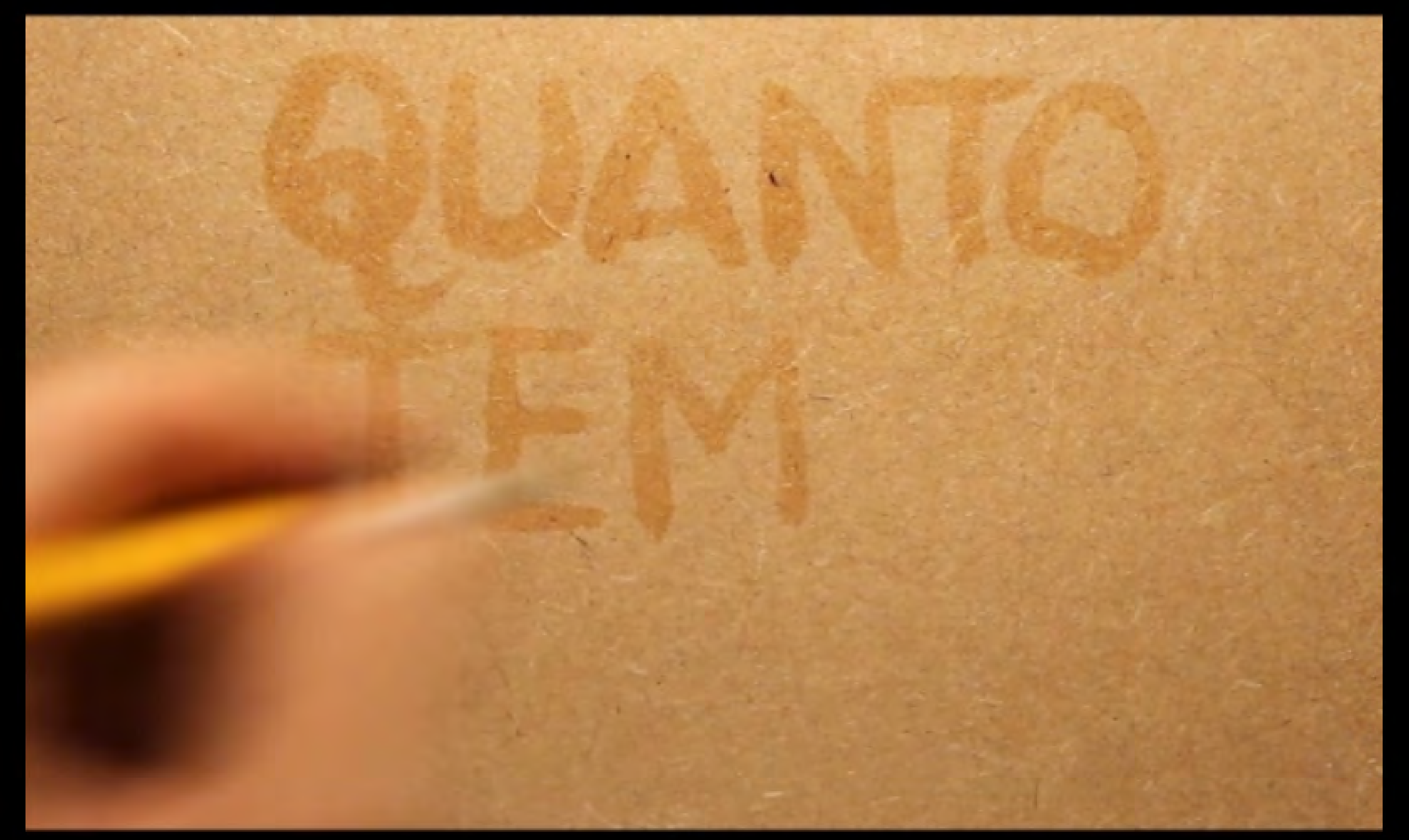




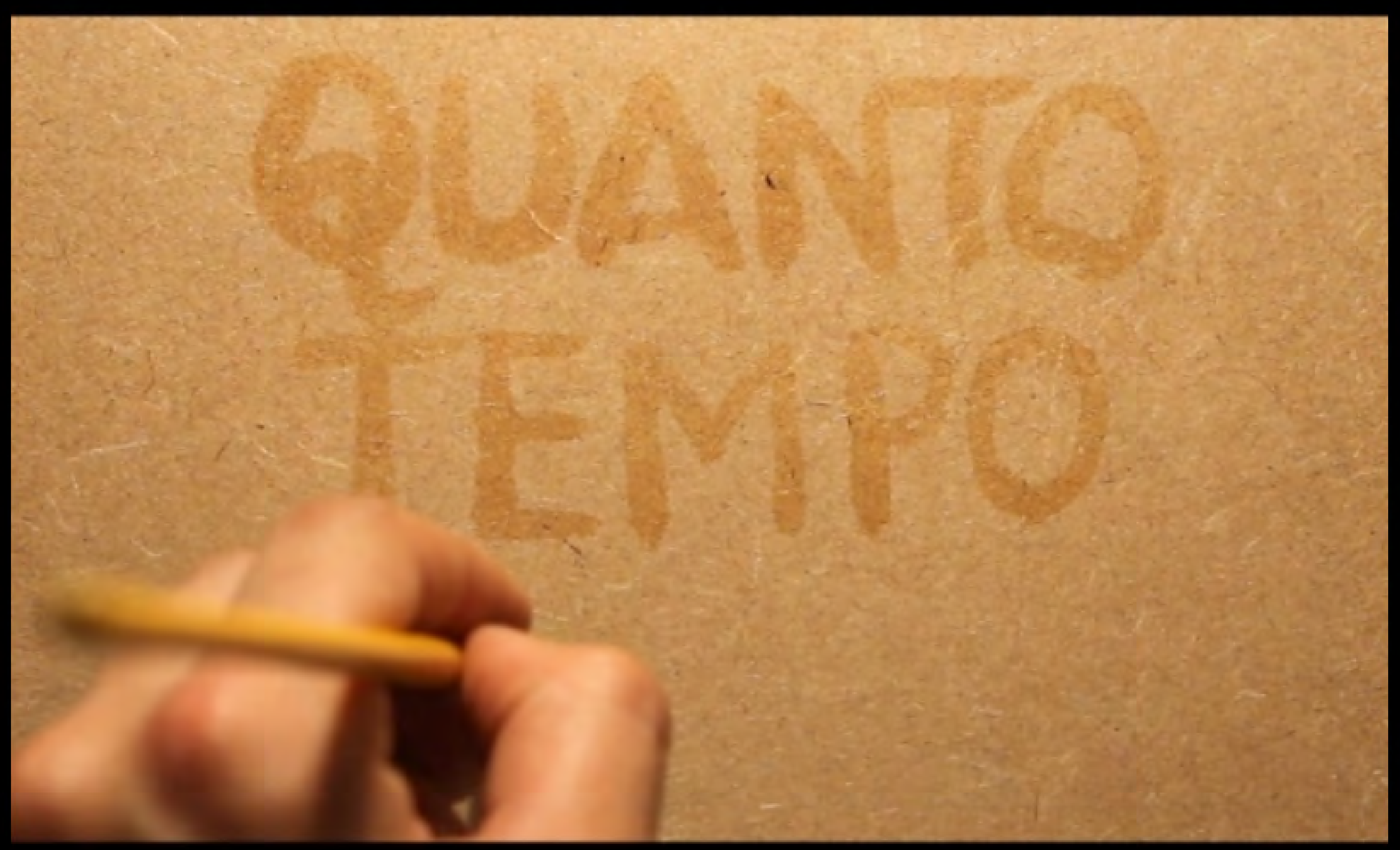




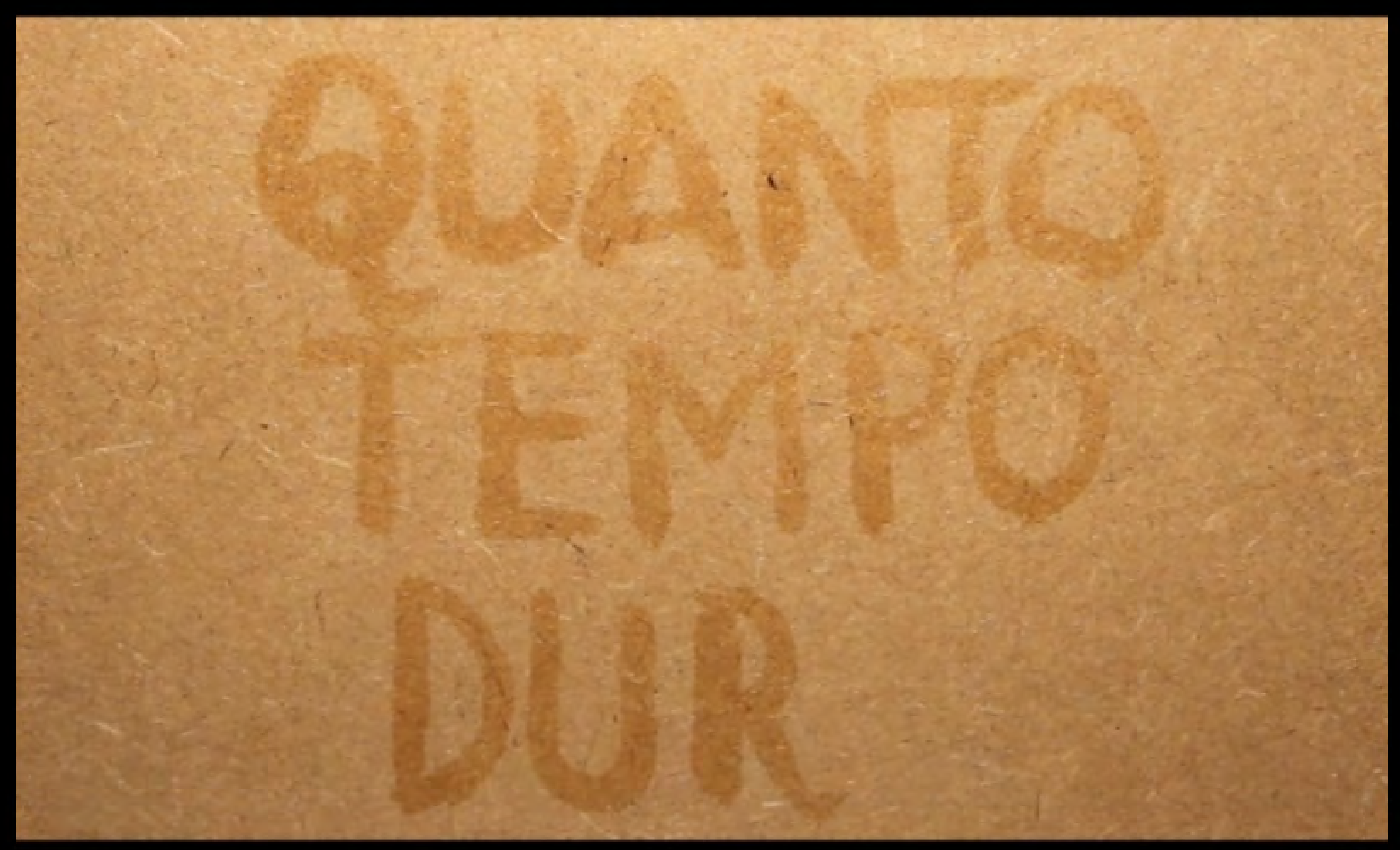




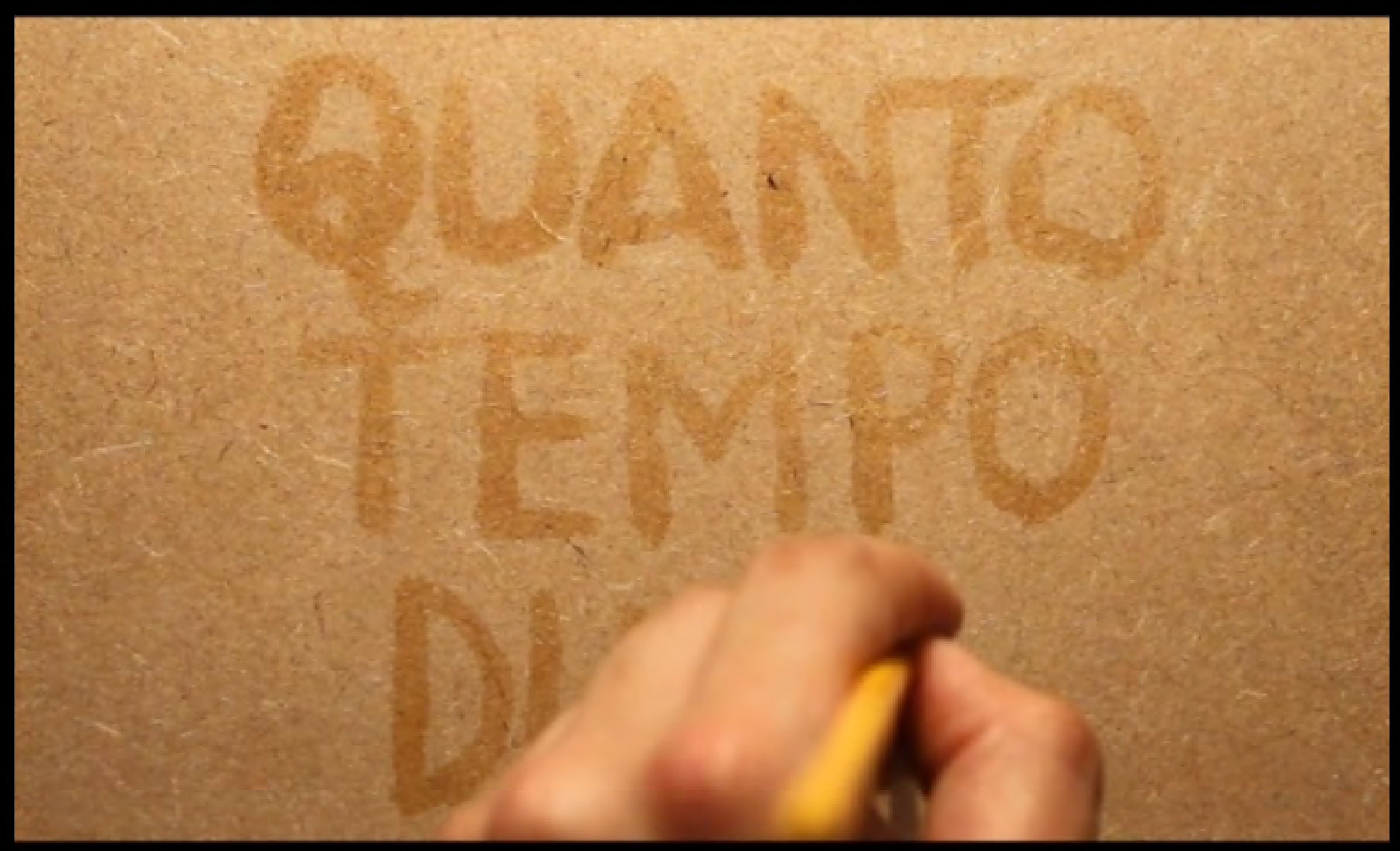




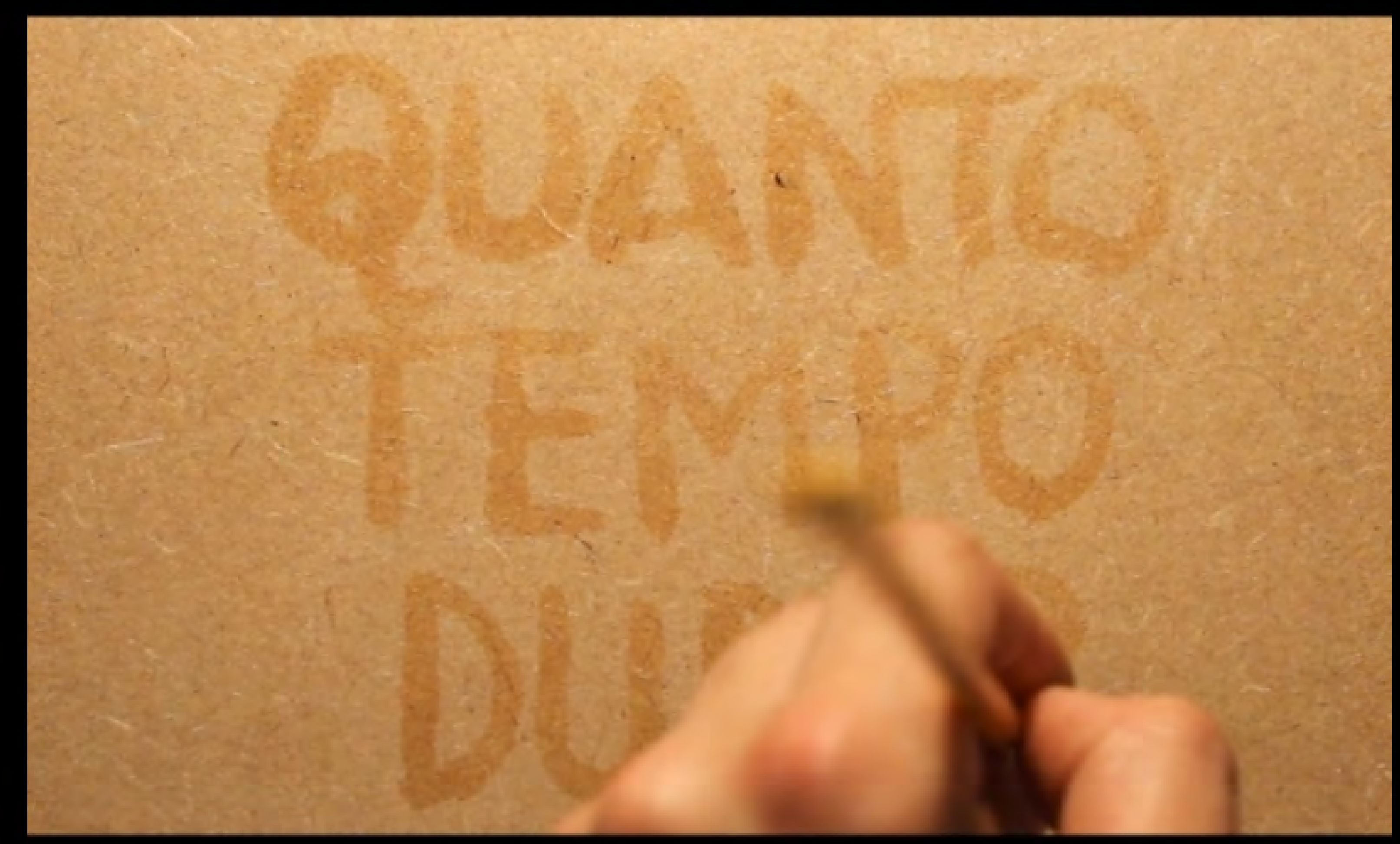




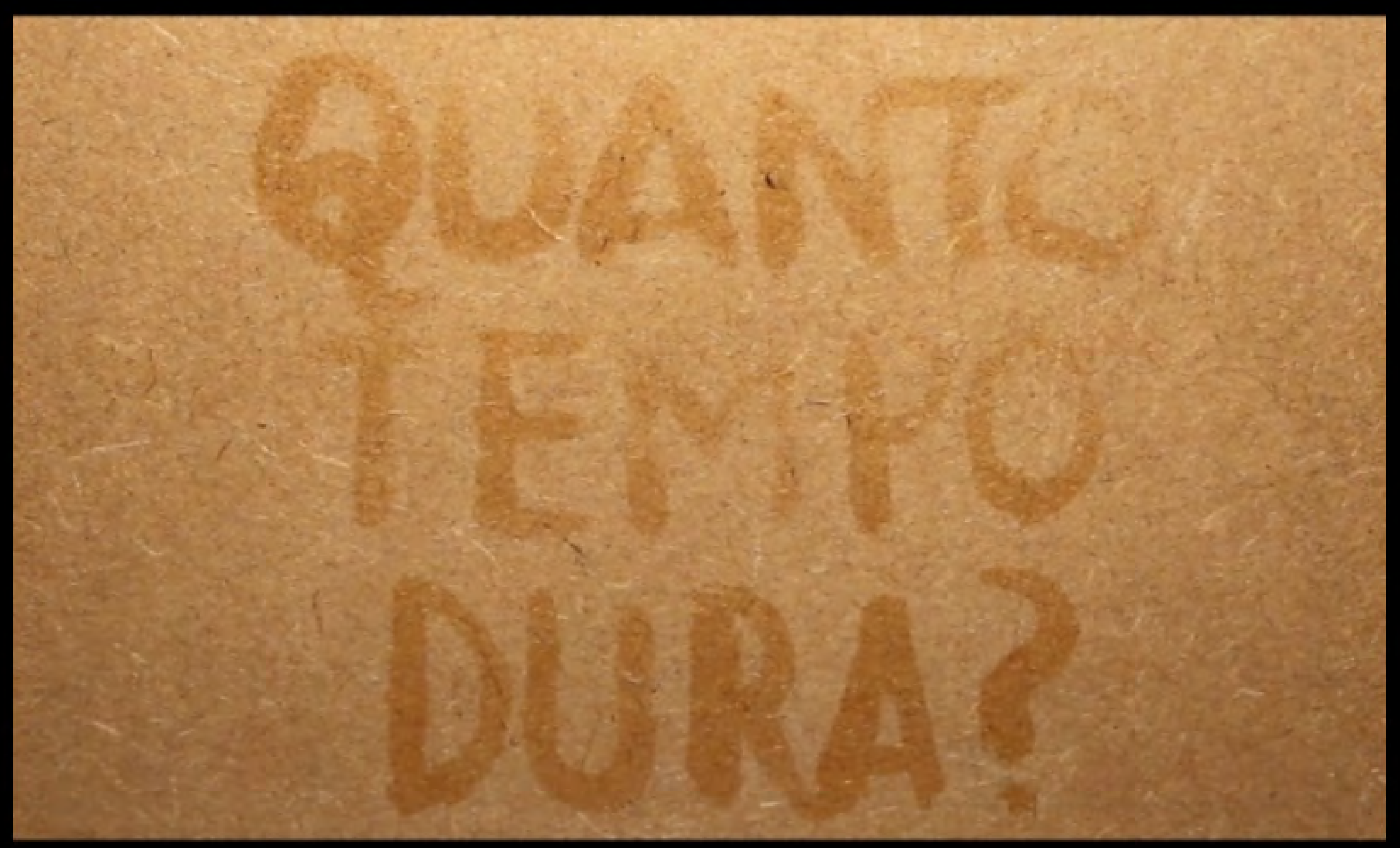




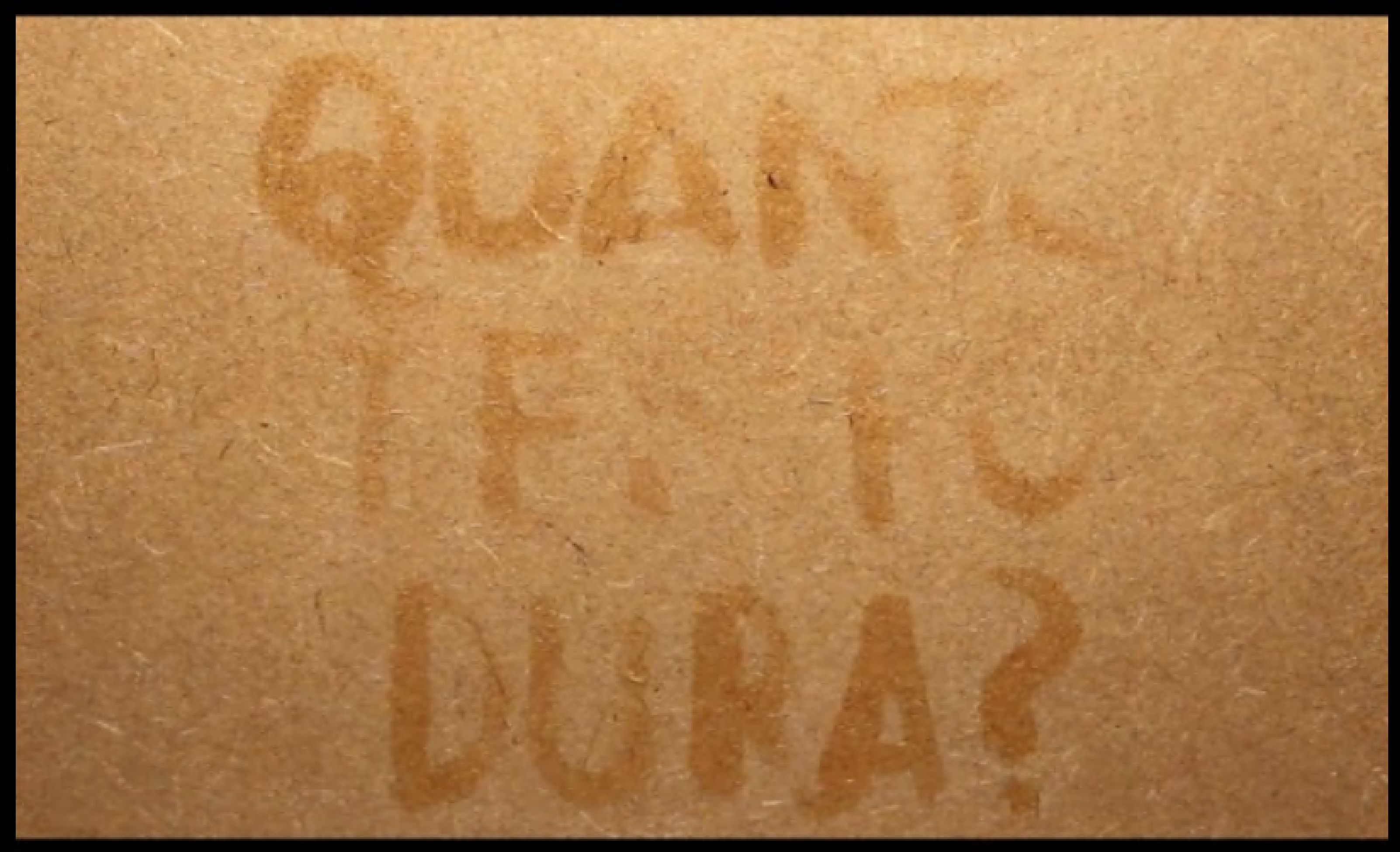




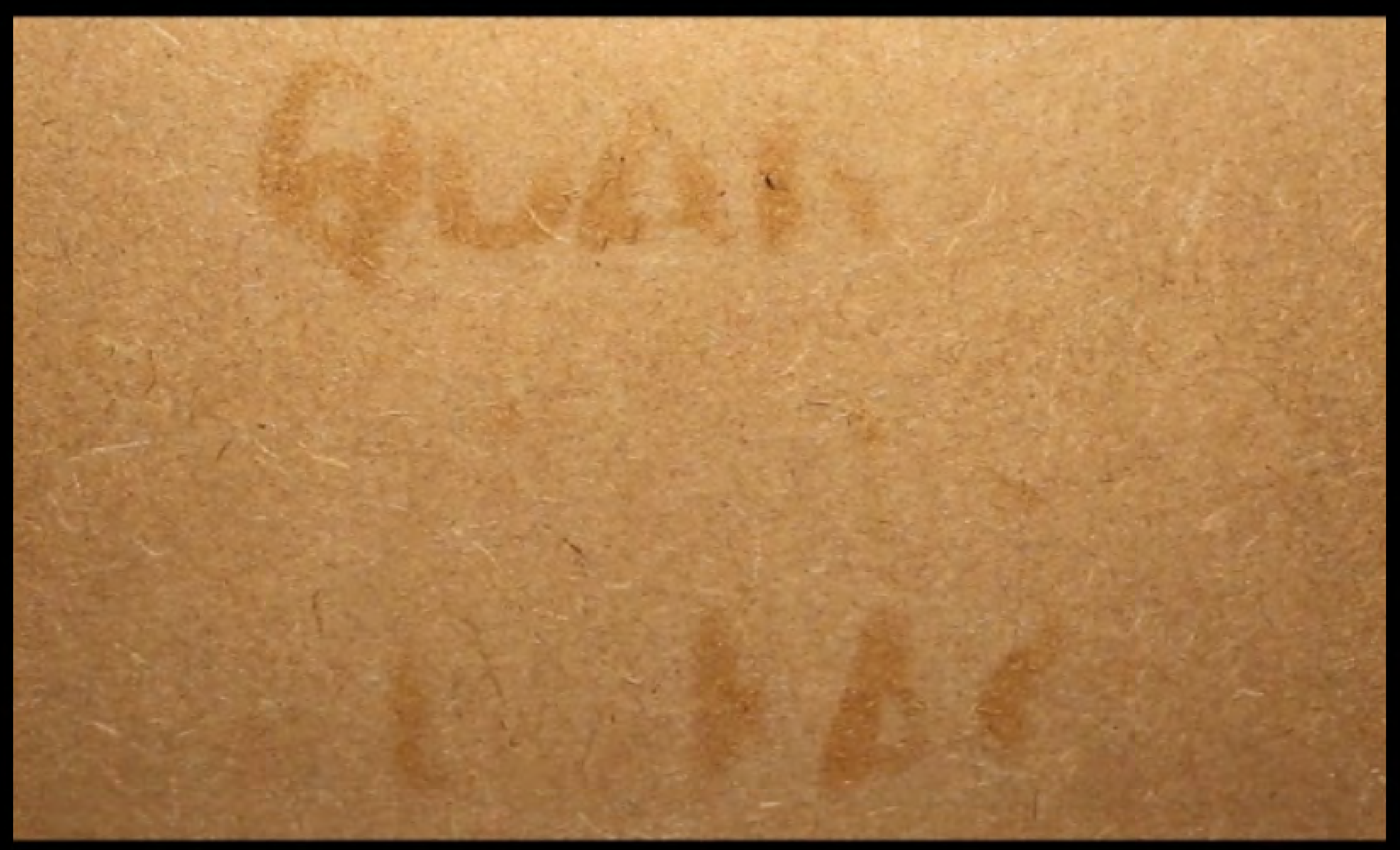




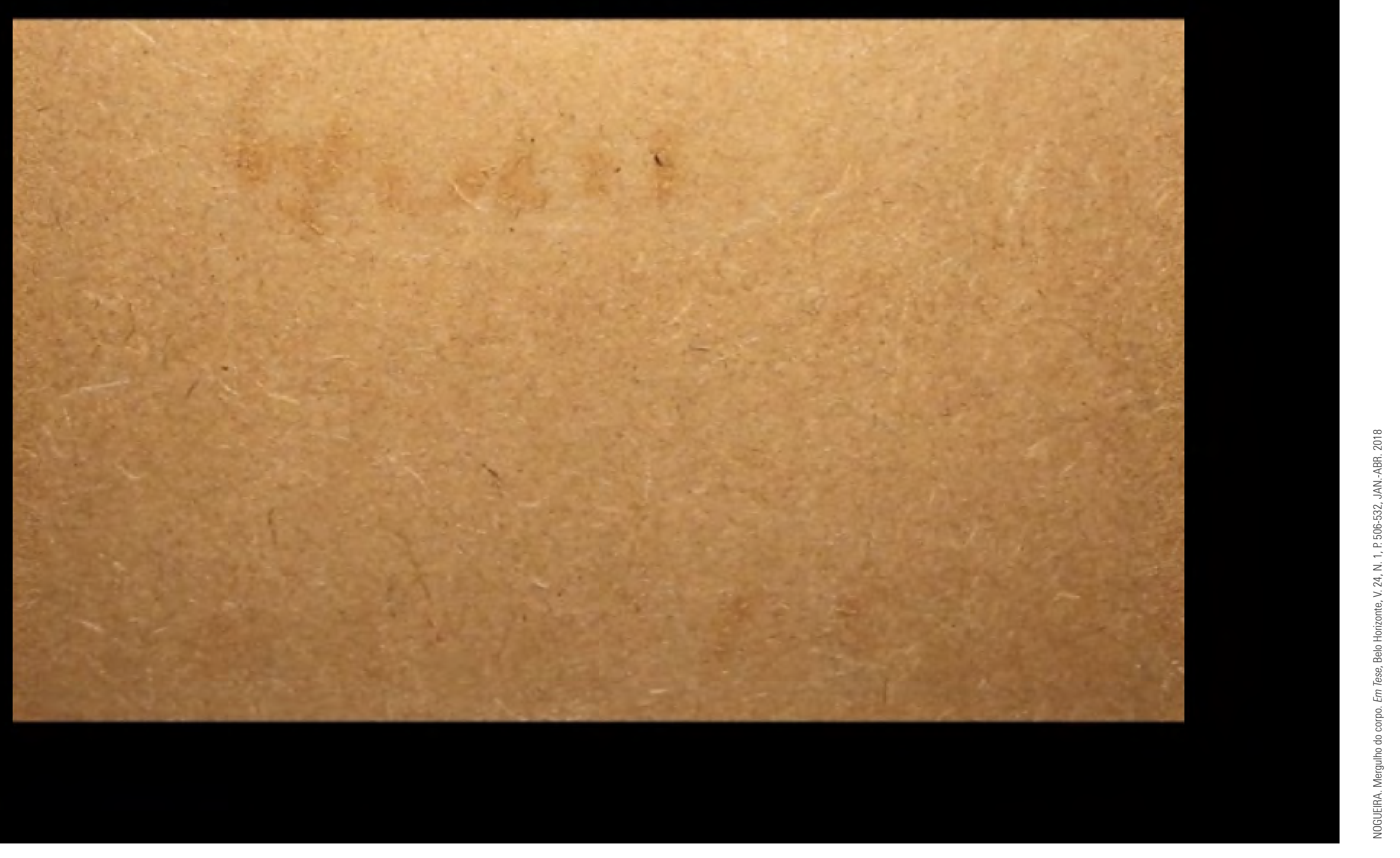




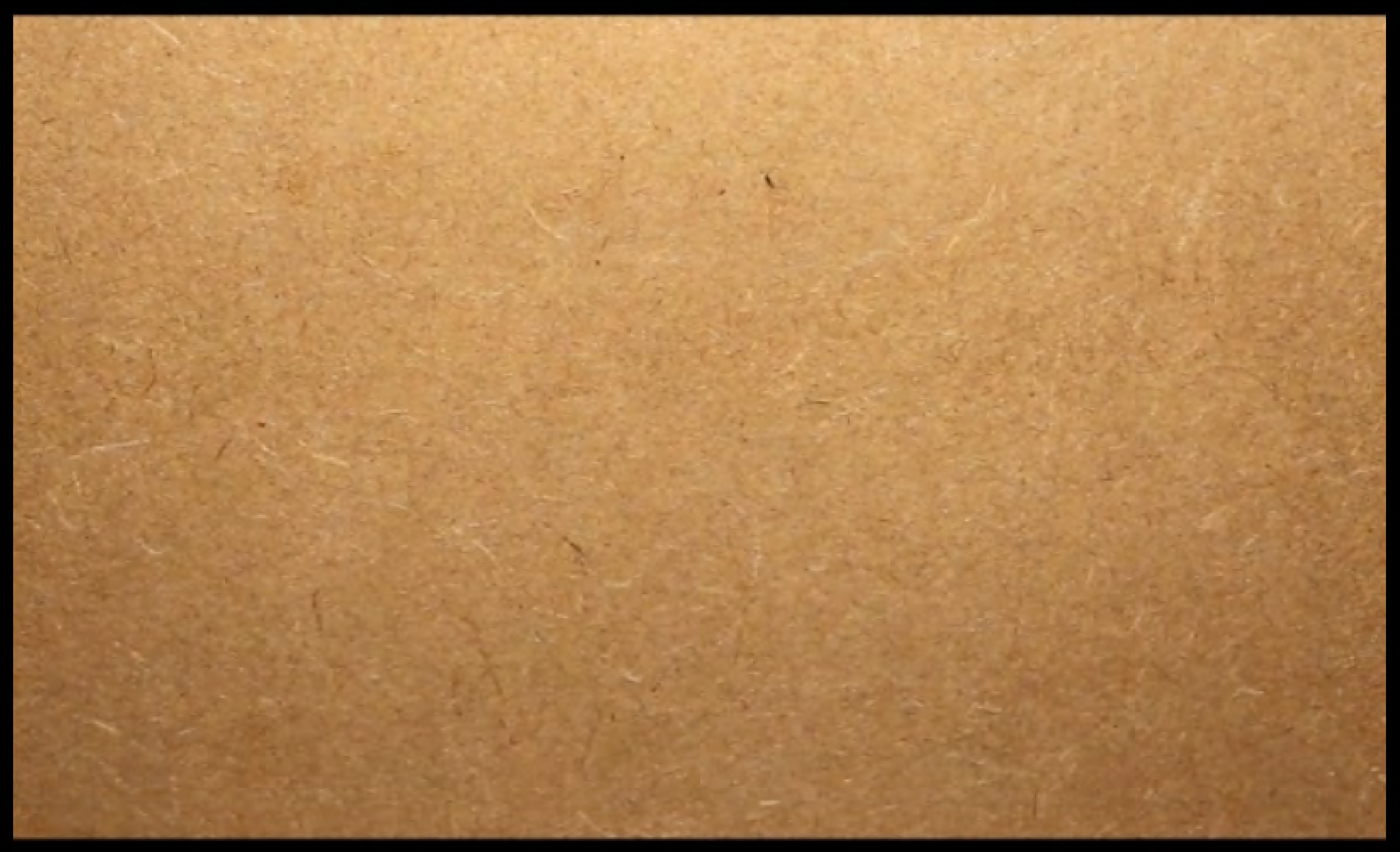

